\title{
CAMBRIDGE
}

New Theatre Titles from Cambridge University Press! titles!

\author{
The Cambridge \\ Introduction to \\ Theatre Directing \\ Christopher INNES and \\ Maria Shevtsova \\ Cambridge Introductions to Literature \\ 575.00: Hb: 978-0.521-84449-9: 295 pp. \\ S24.99: Pb: $978-0-521-60622-6$
}

\section{The Tempest}

Second Edition

William Shakespeare

Edited by DAVID LINDLEY

The New Cambridge Shakespeare

S45.00: Hb: 978-1-107-02152-5: $296 \mathrm{pp}$.

S16.99: Pb: 978-1-107-61957-9

The Cambridge

Introduction to Early

Modern Drama, 1572-1642

JULIE SANDERS

Cambridge Introductions to Literature

575.00: Hb: 978-1-107-01356-8: 240 pp.

S27.99: Pb: 978-1-107-64547-9

\section{Viewing America}

Twenty-First Century

Television Drama

Christopher Bigsby

S99.00: Hb: 978-1-107-04393-0: $450 \mathrm{pp}$.

S29.99: Pb: 978-1-107-61974-6

\section{Shakespeare}

Beyond English

A Global Experiment

Edited by SUSAN BENNETT and $\mathrm{CHR}_{\text {ISTIE CARSON }}$

S80.00: $\mathrm{Hb}$ : 978-1-107-04055-7: 344 pp.

S27.99: Pb: 978-1-107-67469-1

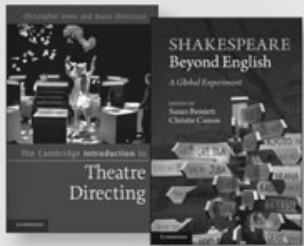

Euripides' Medea

A New Translation

Edited and translated by

DIANE J. RAYOR

S40.00: Hb: 978-1-107-01566-1: 127 pp. S14.99: Pb: 978-1-107-65221-7

The Cambridge Companion to Shakespearean Tragedy Second Edition

Edited by Clatre McEachern

Cambridge Companions to Literature

S85.00: Hb: 978-1-107-01977-5: 321 pp.

S29.99: Pb: 978-1-107-64332-1

The Philosophy of Tragedy From Plato to Zižek

Julian Young

585.00: Hb: 978-1-107-02505-9: 304 pp. S29.99: Pb: 978-1-107-62196-1

\section{Modern British Drama} on Screen

Edited by R. Barton Palmer and WiLliam Robert Bray 595.00: Hb: 978-1-107-00101-5: 300 pp.

\section{Screening Early}

Modern Drama

Beyond Shakespeare

Pascale Aebischer

599.00: Hb: 978-1-107-02493-9: 286 pp.
Celebrity, Performance, Reception

British Georgian Theatre as Social Assemblage

David WorRall

s99.00: Hb: 978-1-107-04360-2: 320 pp.

Beckett and Animals

Edited by MARY BRYDEN

s90.00: Hb: 978-1-107-01960-7: 244 pp.

Samuel Beckett's Library

Dirk VAN Hulle and

MARK NixoN

S90.00: Hb: 978-1-107-00126-8: 342 pp.

Occult Knowledge, Science, and Gender on the Shakespearean Stage

MARY FLOYD-WILSON

S99.00: Hb: 978-1-107-03632-1: 246 pp.

Constructing the Canon of Early Modern Drama

JEREMY LOPEZ

S99.00: Hb: 978-1-107-03057-2: 280 pp.

Mapping Irish Theatre Theories of Space and Place

Chris MORASH and

SHAUN RichaRdS

S99.00: Hb: 978-1-107-03942-1: 250 pp.

A Jacobean Company and its Playhouse

The Queen's Servants at the Red Bull Theatre (c.1605-1619)

Eva Griffith

S99.00: Hb: 978-1-107-04188-2: 280 pp.

Prices subject to change. 


\section{CAMBRIDGE JUURALS}

\section{New Theatre Quarterly}

\section{Editors}

Maria Shevtsova, Goldsmiths, University of London, UK

Simon Trussler, Rose Bruford College, UK

New Theatre Quarterly provides a vital international forum where theatrical scholarship and practice can meet and where prevailing dramatic assumptions can be subjected to vigorous critical questioning. It shows that theatre history has a contemporary relevance, that theatre studies need a methodology and that theatre criticism needs a language. The journal publishes news, analysis and debate within the field of theatre studies..

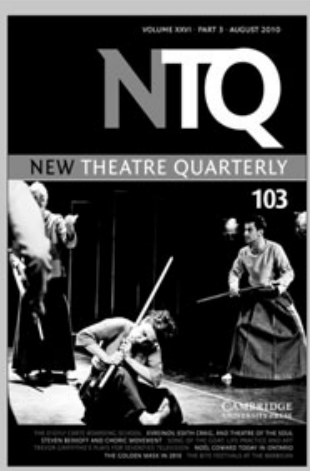

New Theatre Quarterly is available online at: http://journals.cambridge.org/ntq

To subscribe contact Customer Services

in Cambridge:

Phone $+44(0) 1223326070$

$\mathrm{Fax}+44(0) 1223325150$

Email journals@cambridge.org

in New York:

Phone +1 (845) 3537500

$\mathrm{Fax}+1$ (845) 3534141

Email

subscriptions_newyork@cambridge.org

Free email alerts

Keep up-to-date with new material - sign up at

journals.cambridge.org/register

For free online content visit: http://journals.cambridge.org/ntq 


\section{Journal of the Society for American Music}

Published for The Society for American Music

\section{Editor}

Mark Katz, University of North California at Chapel Hill, USA

The Journal of the Society for American Music is an international, peer-reviewed journal dealing with all aspects of American music and music in the Americas. JSAM is dedicated to supporting scholarship that transcends disciplinary boundaries, cutting across historical musicology, music theory, ethnomusicology, cultural theory, identity studies, and American studies. JSAM encourages international dialogue across disciplines. The journal features articles; reviews of books, recordings, and multimedia items; and explorations of special topics.

Free email alerts

Keep up-to-date with new material - sign up at journals.cambridge.org/register

in Cambridge:

Phone $+44(0) 1223326070$

$\mathrm{Fax}+44(0) 1223325150$

Email journals@cambridge.org

\section{in New York:}

Phone +1 (845) 3537500

$\mathrm{Fax}+1(845) 3534141$

Email

subscriptions_newyork@cambridge.org

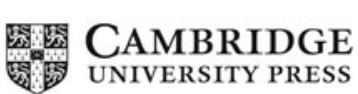




\section{CAMBRIDGE JDURALS}
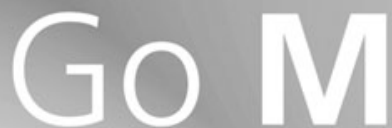

CJO Mobile (CJOm) is a streamlined

Cambridge Journals Online (CJO)

for smartphones and other small mobile devices

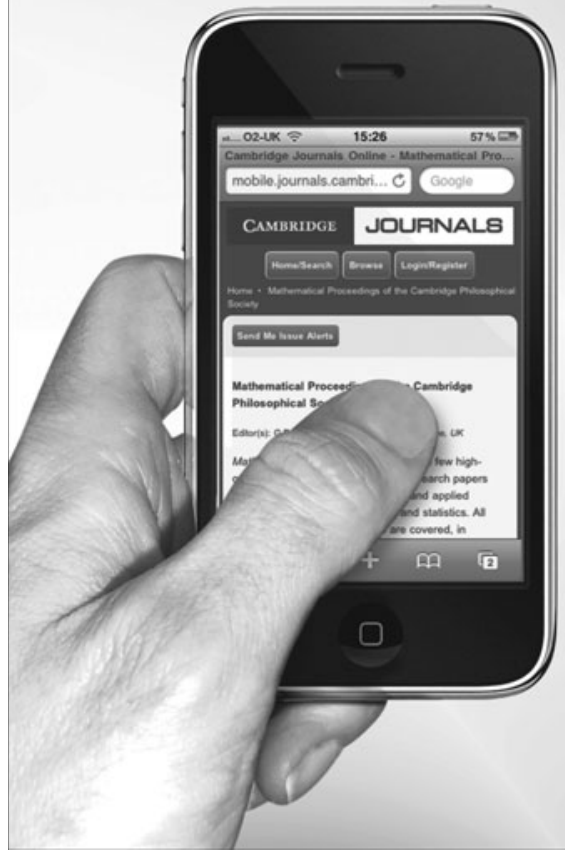

- Use CJOm to access all journal content including FirstView articles which are published online ahead of print

- Access quickly and easily thanks to simplified design and low resolution images

- Register for content alerts or save searches and articles they will be available on both CJO and CJOm

- Your device will be detected and automatically directed to CJOm via: journals.cambridge.org UNIVERSITY PRESS 


\title{
The American Society for Theatre Research
}

The American Society for Theatre Research (ASTR) is a U.S.-based professional organization that fosters scholarship on worldwide theatre and performance, both historical and contemporary. ASTR was founded in 1956 to encourage theatre scholarship in the United States and to provide a link to similar research-oriented organizations, such as the International Federation for Theatre Research/La Fédération Internationale pour la Recherche Théâtrale (IFTR/FIRT). ASTR was incorporated under the laws of the state of New Jersey as a nonprofit corporation in 1967, and is the only theatre organization in the United States formally affiliated with both the American Council of Learned Societies and with the IFTR/FIRT. The ASTR Annual Meeting occurs in the fall of each year.

Theatre Survey, the official journal of ASTR, is published three times a year, in January, May, and September, and is one of the benefits of membership in the Society. ASTR annual dues for North Americans are $\$ 115.00$ for individual members, $\$ 40.00$ for retired members, $\$ 35.00$ for students. Foreign members pay an additional $\$ 7.50$ in each of the above categories. Inquiries about ASTR, including membership, should be directed to:

\author{
Nancy Erickson \\ NEricksn@aol.com
}

The American Society for Theatre Research

P.O. Box 1798

Boulder, CO 80306-1798

Telephone: (888) 530-1838

Fax: (303) 530-1839

http://www.astr.org/

\section{Officers And Executive Committee of ASTR}

\author{
Heather Nathans (President, 2012-2015) \\ Patrick Anderson (Vice-President, 2012-2015) \\ Marla Carlson (Secretary, 2011-2014) \\ Cindy Brizzell-Bates (Treasurer, 2011-2014) \\ Executive Committee members \\ Robin Bernstein (2012-2015) \\ Gay Gibson Cima (2010-2013) \\ Soyica Colbert (2011-2014) \\ Elinor Fuchs (2010-2013) \\ Brian Herrera (2010-2013) \\ Kellyn Johnson (Graduate Student Representative, 2012-2013) \\ Suk-Young Kim (2011-2014) \\ Kirsten Pullen (2011-2014) \\ Jill Stevenson (2012-2015) \\ Shane Vogel (2012-2015) \\ E.J. Westlake (2012-2015) \\ Leigh Woods (2011-2014)
}




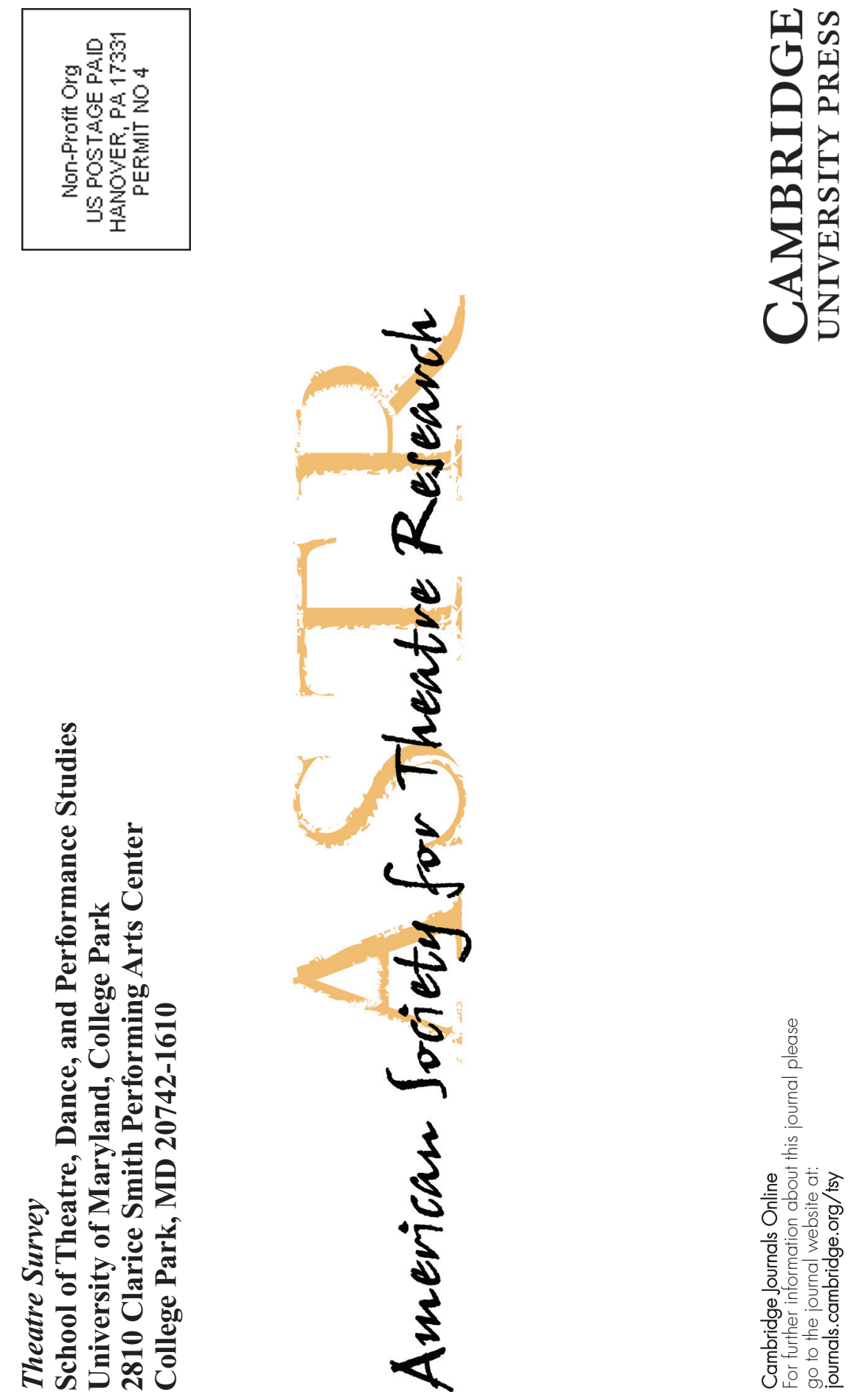

